\title{
ADVOCATE DIRK GYSBERT REITZ: AN ADDENDUM
}

\section{JP van Niekerk*}

Historians will know that research is never completed. It is more often than not terminated or, we like to think, merely suspended because of the constraints of time or the law of diminishing returns. Fortunately there are always others willing to resume the research and to advance it, maybe long after we have moved on, to other topics if not to other realms.

Shortly after the publication of my piece on Dirk Reitz, ${ }^{1}$ I had the pleasant surprise of receiving correspondence ${ }^{2}$ from Dr Kees Briët of Rotterdam, on whose excellent work on the High Court of the Dutch Indies ${ }^{3}$ I had relied heavily for background to Reitz's judicial career in Batavia. Dr Briët filled in some gaps on the Batavian period, and also provided a quite significant piece of information on Reitz's qualifications. With his permission, I recount the information he provided and also add some further shards I uncovered in following up on his references.

1 Earlier this year a new work appeared on the Reitz family. ${ }^{4}$ Despite its promising title (Afrikaner Odyssey. The Life and Times of the Reitz Family), it unfortunately contains little that is new and nothing of interest on our man. ${ }^{5}$

1 Van Niekerk 2016(2): 310-346.

2 On file with the author.

3 Briët 2015.

4 Meredith 2017.

5 Francis William snr is mentioned in passing at 13-15, Dirk not at all.

* Professor, Department of Mercantile Law, School of Law, University of South Africa. 
2 Dirk Reitz obtained a doctorate in law at the University of Utrecht in October $1817 .{ }^{6}$ In November 1844 his alma mater conferred an honorary doctorate on him. ${ }^{7}$ In the published record of the University's graduates, ${ }^{8}$ in which his honorary doctorate is recorded, there is more. Apart from his name and his then position as "supremae curiae in India Batavia senator", the entry also states that Reitz was "Juris utriusque Dr Universitatis Absedonensis". Stumped at first, Dr Briët soon worked out that the "Absedonensis" was a misspelling for "Aberdonensis". Reitz therefore had another doctorate, one from the University of Aberdeen. This lead to the records of that institution which soon provided the answer. ${ }^{9}$ On 14 October 1818, Dedericus Gisbertus Reitz, an LLD from Utrecht, received his doctorate from Aberdeen. Significantly, but, as will be explained shortly, erroneously, the entry on Reitz then adds: "It being necessary for the candidate to attain a degree of LLD from a British University, in order to enable him to practise before the courts at the Cape of Good Hope, his native country." This, at least, settles my query as to whether the introduction of English as the exclusive language to be used in Cape courts was a (contributory) reason for Reitz's departure: ${ }^{10}$ he no doubt had a command of English, which is not to say that the clear signs of the imminent anglicisation of the legal administration at the Cape did not remain an important consideration in his decision to emigrate.

3 Holding two doctorates - the one Dutch, the other British - naturally made Dirk Reitz an exceptional, if not unique member of the Cape bar which, as I have shown, had its fair sprinkling of doctors. However, it is not quite correct that he had to obtain a British doctorate to practise at the Cape. The requirement of a British qualification or experience for admittance as an advocate by, or for appointment to the bench of, the newly created Supreme Court, was only laid down from 1828, long after Reitz had left the Cape. Article III of the Royal Charter of Justice of 24 August $1827^{11}$ provided that the Supreme Court's judges "shall be Barristers in England or Ireland, or Advocates admitted to practice in Our Courts of Session in Scotland, or in said [ie, the Cape] Supreme Court". As is known, the judges making up the bench were

6 See par 5 at 316 of my article.

7 See par 11 at 336 of my article.

8 Van Cittert-Eymers 1963: 52.

9 Anderson 1898: 103. The University of Aberdeen was created in 1860 when Marischal College (founded in 1593) and King's College, Aberdeen, merged. There is no mention of any Reitz in the latter's records: see Anderson 1897.

10 See par 6 at 323-325 of my article.

11 The Charter, which came into operation on $1 \mathrm{Jan} 1828$, is published in the Cape of Good Hope Government Gazette of Tue 11 Dec 1827 (and formally entitled, HM's Royal Charter, for the better and more effectual Administration of Justice within the Colony of the Cape of Good Hope). For a reprint, see Theal Records of the Cape Colony vol 32: 274-292; and see, further, Visagie 1978. 
imported from Britain and no local advocate (or for that matter, no judge on the local Court of Justice) was seriously considered for appointment. In all probability, Reitz, despite his two doctorates, would not have been found suitable on the basis of having practised at the Cape. In order to be admitted to practise before the new Supreme Court as an advocate, according to article XVII of the Charter, applicants had to have been "admitted as Barristers in England or Ireland or advocates in the Court of Sessions of Scotland or to the degree of Doctor of Laws at Our Universities of Oxford, Cambridge or Dublin". This did not apply to advocates already previously admitted to practice, as would have been the case with Reitz, had he stayed on. Ironically, of course, even had Reitz returned to the Cape after 1828, he would not have qualified, his doctorate being from one of the "less prestigious" British universities! ${ }^{12}$

4 I had recorded that Reitz had left the Cape for Batavia in mid-1824 and that he had commenced practice as an advocate there by September of that year. ${ }^{13}$ This is confirmed by a resolution number 24 of the governor-general ${ }^{14}$ of the Dutch Indies of 26 August $1824,{ }^{15}$ granting Reitz, at his request, permission to reside on the island of Java, more specifically in Batavia, and to practise as advocate before the local courts, on payment of fl300 per month from public funds ("uit "s lands kas te Batavia") for a period of six months to provide him with sufficient means of subsistence. ${ }^{16}$

5 In July 1833 Reitz was appointed as a permanent member of the Court of Justice at Samarang. ${ }^{17}$ This occurred by resolution number 1 of the governor-general of 20 July 1833. ${ }^{18}$ Earlier, in October 1832, he was, on the death of one of its members (JWD

12 Unless it could be argued that his earlier admittance still sufficed to allow him to practise despite his having left the colony.

13 See par 6 at 322-323 and par 8 at 328 of my article.

14 Incidentally, in n 110 of my article at 327, I had the name of one of the three first post-British commissioners-general in 1816 wrong: he was Cornelis Theodorus Elout (not Ekhout).

15 NL-HaNA, Koloniën, 1814-1849, 210 01, inv nr 2784. The decisions and resolutions of Dutch East Indian governors-general are taken up in the Dutch National Archives in The Hague (NLHaNA), as part of the archives of the Ministry of Colonies (Ministerie van Koloniën, KOL), which holds the archive inventory number 21001 . East Indian gubernatorial decisions and resolutions "buiten rade" (ie, made by the governor without the consent of the Council of India), from 18161849 , appear in 291 vols with inventory numbers 2435-2725; those decisions and resolutions of the governor "in rade" (ie, made by the governor-in-Council), from 1819-1836, appear in 94 vols with inventory numbers $2770-2863$. The resolution referred to here appears in inventory number 2784, which covers decisions and resolutions during Aug-Sep 1824. Again Dr Briët went way beyond the call of collegiality to supply me with electronic versions of the relevant archival documents referred to in this addendum, indispensably so as, at the time of writing, this part of the Dutch National Archives was not available for reasons of digitalisation.

16 This settlement amount was paid to encourage young lawyers like Reitz to settle and practise in Batavia.

17 See par 10 at 332 of my article.

18 NL-HaNA, Koloniën, 1814-1849, 210 01, inv nr 2848. 
de Jongh), appointed as temporary member of that Court. This was after, in August of that year, he had qualified as an East Indian official ${ }^{19}$ because, so it was stated, he could in the current circumstances not make a proper living as an advocate..$^{20}$ One can only speculate about this, but probably (hopefully) it was not because of Reitz's qualities as a lawyer but because of a lack of legal work in Batavia. In March 1836 Reitz was back in Batavia, elevated to the High Court there. ${ }^{21}$

6 In 1847, Reitz was appointed as president of the Batavian Orphan Chamber. ${ }^{22}$ This occurred by gubernatorial decision no 2 of 26 January $1847 . .^{23}$ The decision itself provides some background information. The death of the previous president, $\mathrm{JH}$ Hofmeijer, had created a vacancy while another member, A Houtkoper, had received two years' home leave in December 1846. Furthermore, the imminent introduction of codification in the East Indies would involve the Orphan Chamber in new duties and subject it to new laws. As a result, so Hendrik Ludolf Wichers, president of the High Court reported to the governor-general in that December, it would require the Chamber's president to be a lawyer, able to guide its other members on legal matters. So, although the High Court would by the acceptance of Reitz's application for the post, lose a capable member, president Wichers nevertheless supported his appointment. By the same decision, the monthly salary of the Chamber's president was increased from fl 800 to fl1000, the additional amount to be funded from the Chamber's income. ${ }^{24}$

7 Finally, in the Iconographic Bureau Collection of the Dutch Rijksbureau voor Kunsthistorische Documentatie (RKD) in The Hague, there is a silhouette portrait of Dirk Gijsbert Reitz by an unknown artist. ${ }^{25}$ Alas, it shows little more than a shadowy outline, appropriate, I suppose, for a man of which much more no doubt remains to be uncovered.

19 "Reitz ... kunnen worden beschouwd als het radikaal van Indisch ambtenaar te bezitten."

20 See resolution no 22 of 31 Oct 1832: NL-HaNA, Koloniën, 1814-1849, 210 01, inv nr 2845.

21 See par 10 at 333 of my article. On his incapacity as member of that Court to stand surety, see gubernatorial decision no 20 of 3 Jul 1838: NL-HaNA, Koloniën, 1814-1849, 210 01, inv nr 2584 .

22 See par 11 at 335 of my article.

23 See NL-HaNA, Koloniën, 1814-1849, 210 01, inv nr 2690.

24 Hopefully that secured Reitz's financial position, for as late as October 1843 he still applied to take over the contract for running the existing governmental tea garden (probably a tea plantation) in the suburb of Kadoe, unsuccessfully so as "het voornemen niet bestaat om theetuinen in de residentie Kadoe bij kontract aan particulieren af te staan": see decision no 6 of 15 Oct 1843: NLHaNA, Koloniën, 1814-1849, 210 01, inv nr 2650.

25 See https://rkd.nl/en/explore/portraits/128272 (accessed 14 Feb 2017). 


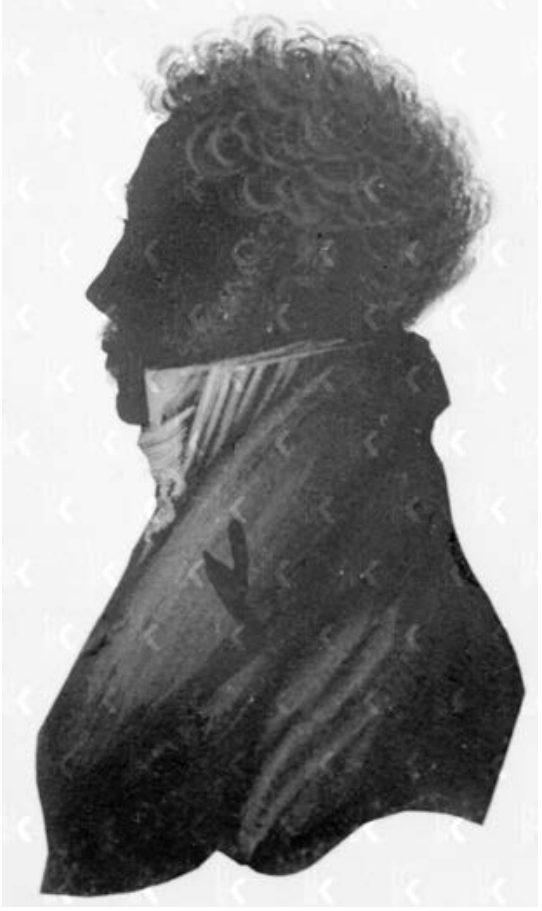

\section{BIBLIOGRAPHY}

Anderson, Peter John (1897) Officers and Graduates of University \& King's College Aberdeen, MVD-MDCCCLX (Aberdeen)

Anderson, Peter John (1898) Fasti Academiae Mariscallanae Aberdonensis. Selections from the Records of the Marischal College and University, MDXCIII-MDCCCLX, Vol II: Officers, Graduates, and Alumni (Aberdeen)

Briët, Kees (2015) Het Hooggerechtshof van Nederlands-Indië 1819-1848. Portret van een vergeten rechtscollege (Amsterdam)

Meredith, Martin (2017) Afrikaner Odyssey. The Life and Times of the Reitz Family (Johannesburg)

Theal, George McCall (1897-1905) Records of the Cape Colony 35 vols (Cape Town)

Van Cittert-Eymers, JG (1963) Album promotorum der Rijksuniversiteit Utrecht 1815-1936 en Album promotorum der Veeartsenijkundige Hoogeschool 1918-1925 (Leiden)

Van Niekerk, JP (2016) “The life and times of Cape advocate Dirk Gysbert Reitz: A biographical note" Fundamina. A J of Legal History 22(2): 310-346

Visagie, GG (1978) Charter of Justice 1828-1978. A Short Commemorative History [150 ${ }^{\text {th }}$ Anniversary Commemorative Brochure] (Cape Town) 